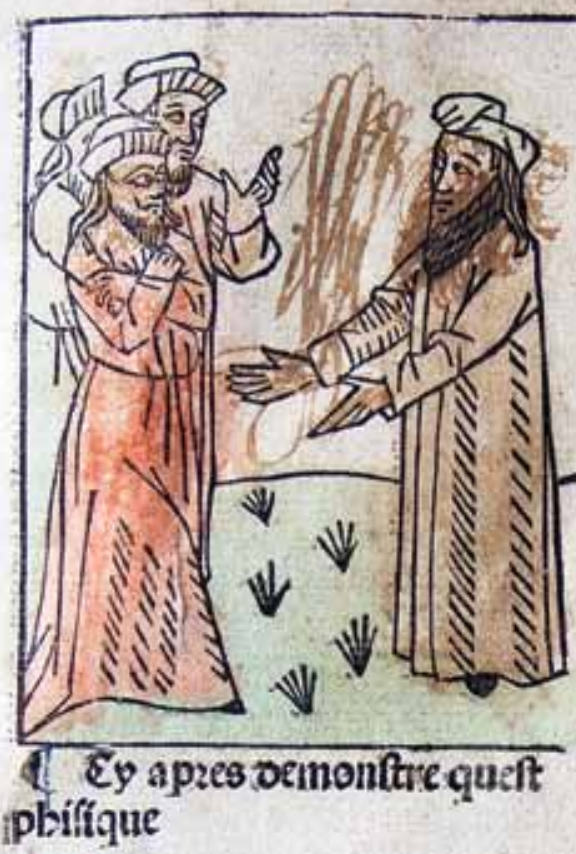

D (ondre oaulenne par tic oe pbifique pour entendice miculr ce qu dirons Sísirons pzemierement queft plifífque - Dbifíqueefit vie ficience par quzoy lon corignoift toutes les manierce ou coaps oe lomme et par laquelle lon garoeta fä te ou cosps et remue tes mala Dies Et pouons oire que cefte fíence a denx partícs Zune $\mathbf{p}$ tie eft appellee tbeosique par laquelle nous fauons cognoif tre et ingier tous les commas ocmens oe pbifique Eeft cong noiftre ct frauoir quils fout ifi manieres oe fieures 2 une $\mathrm{ma}$ gnicre oe fieure fi aouient quät les bumeurs font cozrumpad et ecite maniere appellent les pbíficiens febzís putrida $\mathbf{L} a$ tre fi aduíent es membres $\mathrm{la}$ वै le fappelle etbique 2 a tierce if aouient oes éperis laquelle ap pellent affinicra et ces commä oemens et auteres quí fappar tienne a pbifique fauons par tbeoziq ( Đar pzatiâ fauós nons comment on doit ouure a gavder la fante $z$ a remougíz les malasties É ommencons dó ques comment lon aoit fanoir la fante garderpar pzatique 1 laifisis citer Ia tbeozique pour ce ä deileneft pas noftre itécí on oe parter ec commencerons peemierement of lair

Cepremier cbapitre eft oe laír acognoiftre le bó zleman uais ou pzouffit oujico2ps

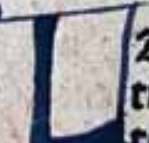

Zlirfi eft ving oes qua tre elemis oclquely tou teachofes four faictes $x$ fourmees fromme nous anös

bif

The first page of Le livre pour la santé du corps garder, by Aldobrandino of Siena, a book about the preservation of health, which was printed in Lyon about $148 \mathrm{I}$ and is described in the article on pp. 372-375. This is the earliest known medical book to have been written in French as opposed to translated into French.

There is not, and never was, either title or title page but the Sibbald Library's copy does lack the first two leaves which contain an introduction and list of contents. The rather crude colouring of the woodcut is probably contemporary. The chapter capitals and paragraph signs (T) are drawn in red or blue ink after printing, a technique known as rubrication, and some paragraphs have decorative scrolling to fill the last line. Whether the apparent scribble (in ink) on the woodcut is a monogram or signature of some kind is not clear nor has the annotation at the bottom of the page been deciphered. 


\section{Le livre pour la santé du corps garder}

This is probably the rarest printed book in the Library; only five copies are known. Our copy lacks the first two leaves (as does that in the Bibliothèque Nationale de France) but I have been able to examine a complete copy held in the Hunterian Collections of Glasgow University. The image right shows the first page of the text proper containing a woodcut probably representing the author (on the right) presenting his work to three others. The image is quite crudely coloured. The book is a treatise on the preservation of health, and is not, as the author is at pains to point out, concerned with the treatment of disease. It is the first medical work known to have been written in French rather than translated from an earlier work in another language such as Latin. It exists in quite a number of manuscripts of the thirteenth to fifteenth centuries. There is only one printed edition which all catalogues agree is from Lyon around 1480. However, there has been a divergence of views about who printed it.

\section{THE TEXT AND ITS AUTHOR}

The manuscripts known in 1911 were studied in detail by Landouzy and Pépin.' They provide a transcription of the oldest manuscript $A^{*}$ together with the variants in three of the other manuscripts. Manuscript $A$ begins with a prologue which is not part of the text itself but describes its authorship and how it came to be written. Since the prologue is entirely in the third person it seems to have been written not by the author of the text but by someone else describing it, perhaps an early scribe or copyist. There is no reason to doubt the account of how the book came to be written which accords well with the known history of those mentioned.

We learn then, that the book was written in 1256 (en l'an de l'incarnation de Jhesu Crist m.cc.lvi. ans...) by Alebrans de Florence for, and at the request of, the Countess of Provence (Béatrix de Savoie) 'mother of the queen of France, the queen of England, the queen of "Almaigne"t, and the Countess of Angou'; the Countess of Angou later became queen of Sicily. The occasion of writing was a visit Béatrix was going to make to her daughters. Aldebrandin wrote the book because he was unable to accompany his mistress since she required him to remain to look after 'merchants from over the mountains' (i.e. from Italy) whom he was treating. From the dates of the marriages of Béatrix's daughters and the dates when their husbands acceded to, or were elected to, their thrones, it is likely that the book was indeed written in 1256.

In 1847 Littré$^{2}$ named 'Alebrand de Florence' as the author of three manuscripts of the book on preserving health that he had examined; from his quotations it is clear that one of these was Landouzy and Pépin's manuscript $A$, the earliest known. Of 'Alebrand' he says 'we have no information beyond that contained in the manuscripts.' In I9II Landouzy and Pépin repeat this but then add that, in $1906,{ }^{3}$ the philologist Antoin Thomas, who wrote a preface to their book, had suggested that the author of the text is probably to be identified with a certain Aldobrandinus de Senis who had lived and practised in Troyes in the province of Champagne. Thomas had found in a transcription of a cartulary of the diocese of Troyes a reference to the bequest of his house by a certain magister Aldobrandinus de Senis physicus Trecis commorans ('master Aldobrandinus of Siena, physician, living in Troyes') to the religious house of Saint-Antoine de Viennois. As Thomas says, how can one resist identifying him with the author of our text who is named in four of the manuscripts as Halebrandis (in two manuscripts), Halebrandit and Aldebrandins, in each case from Siena, variously spelled? Landouzy and Pépin also consider the possibility that Aldebrandin was one of the physicians of Louis IX (Saint Louis), perhaps recommended to him by his old mistress Béatrix. Beyond the fact that his name is coupled with that of the French king in two manuscripts and in the colophon of our printed book, there seems to be no real evidence that he was a royal physician - though, of course, he could well have been - the dates allow it.

One of the obvious puzzles of the work is why an Italian should have chosen French rather than his native Tuscan when he wished to write his treatise in the vernacular. It also seemed strange that, if the work was indeed written for Béatrix de Savoie, Countess of Provence, it should have been written in old French (langue d'oil, northern old French) not in Provençal or another dialect of Occitan (langue d'oc). Thomas suggests in his 1906 paper, and expands on this in his preface of $191 \mathrm{I}$, that for a physician 
who had apparently settled in Champagne this would have been a perfectly understandable choice. He also comments on the dialect of the text noting that not only is it northern, it has characteristics of Picard and Walloon dialects of the northeast and French Flanders. He suggests that perhaps Aldebrandin had spent time in the north-east and/or may have had a scribe or secretary from that region. It also transpires that there were close trade links between Champagne and northern Italy and that Italian merchants would not have been uncommon visitors to Troyes (which had one of the largest markets in the province). Over all, Thomas's identification of Béatrix's physician and our author with this practitioner who was settled in Troyes, where he owned a house and died in 1287, would largely explain the use of the northern dialect and has much to recommend it.

But all this early twentieth century scholarship was directed exclusively at the manuscripts. Landouzy and Pépin's scholarly treatise devotes but a single page to 'three known copies of an edition published [printed] at the end of the fifteenth century' of which only one was complete. They suggest it derives from a late (i.e. fifteenth century) manuscript and point out that, in addition to a number of omissions, it offers the reader 'several completely false passages that diverge markedly from the original [manuscript] versions'.' As to the immediate origin of the copy the printer used, who can say? The other remarks are not unjust. However, the printed book is much more interesting than this rather summary dismissal might suggest.

\section{THE BOOK}

Aldebrandin's (the French version of his name) book on the preservation of health is the first printed medical work in French which was derived not from a Latin (or Greek via Latin) original but was written in French. The book's language and orthography is, not surprisingly, considerably closer to modern French than that of the parent manuscript; it is better described as 'middle French' than 'old French'. It has neither title nor title-page and is known either by a short version of the first line of the text or just as Le régime du corps.

The prologue which provides so much information about the writing of the work is not included but the author is named in the first line of the first page (missing from our copy) and the usual catalogue title derives from this incipit: 'Cy commence le livre de maistre aldebrandin pour la sante du corps garder et de chascu[n] membre pour soy garder et conserver en sante.'

The colophon at the end of the book contains neither date nor printer's name and says simply: 'Cy finist le livre que maistre aldebrandin fist a la req[u]ste du roy de fra[n] ce pour la con[ser]vacion de la sante du corps humain.' (Figure I).

\section{pbizonomie $2 c$ q̄ left le quart et le vltime $z$ oarrenier tractíe ou liare \\ Ey finift le liure que maiftre aldebranoin filt a la reqifte ou roy oe fräce pour la conf uacion oe la fante du cospsbumaín}

FIGURE I The end of the text and colophon. The rubricated paragraph sign I was drawn in red ink after the sheet had been printed. Note the contractions of req[ue]ste, fra[n]ce and con[ser]vacion.

From the colophon one supposes that the text available to the printer did not contain any of the information about the origin of the book which we have seen some manuscripts have as a prologue, but perhaps did have information from some of the others which claim an association between the author and the French king.

The text is printed without periods (full stops) or any other mark at the end of sentences; these do begin with a capital, however. It was printed to be rubricated, that is, to have initial capitals for chapters drawn in with the pen; spaces are left for this and for the addition of drawn paragraph marks, $\mathbb{\Upsilon}$ (see Figure I). In our copy the initial capitals and paragraph signs are drawn alternately in red and blue, with occasional lapses in colour sequence and with some omitted. Some paragraphs with short terminal lines are decorated with scrolling in red or blue to fill the space. Paragraphs do not always begin on new lines. All these features are common in printing of the late fifteenth century.

As is common in early printing, heavy use is made of contractions; these derive from manuscript usage and their use in early French printed texts follows fairly closely the Latin usage.The compositors made liberal use of contractions to justify the lines so that they fitted exactly into the set width of the text block. While text justification in manuscripts was primarily a matter of aesthetics, in printing it is essential; the type must fill the line exactly so that all the lines of type, each exactly the same length, can be clamped up tightly in the chase before they are put on the bed of the press. Neither the pages nor the sheets of the book are numbered.

\section{THE PRINTER}

Claudin, ${ }^{4}$ in his monumental survey of French printing in the fifteenth and sixteenth centuries, attributes the printing of the book to Martin[us] Huss or Husz without 
further comment though, from the context, it is clear that the attribution is based on the details of the typeface. I have compared Claudin's photographic facsimiles of pages from Martin Huss's print shop with images of our copy of the Aldebrandin using the digital technique I have described elsewhere ${ }^{5}$ and have been able to confirm that the type of the Aldebrandin, is, indeed, that used by Martin Huss in his signed and dated Odofredus of 1480 . In the absence of any information about the printer in the book itself, the identification of the type is probably the best evidence available that the attribution to Martin Huss in most modern catalogues is correct.

Though he was not a particularly prolific printer and had a very short career as an independent printer in Lyon, Martin Huss has the distinction of having published the first illustrated printed book in France, Le Mirouer de la Rédemption, in 1478. This work is a French version of the late mediæval Speculum Humanæ Salvationis; the 256 woodblocks for the illustrations probably came from Basel where they had been used to illustrate a German edition.

\section{THE TYPE}

Claudin says the type used in the Aldebrandin originated in Nuremberg and this may well be so. Martin Huss used it for several books suggesting that he may well have had the matrices if not the punches; type does not last long in good condition and was often re-cast after printing a few books and, at this early stage, most printers cast their own type. In any case, the type is a very good example of a rotunda typeface, a style in which the heavy ornamentation of many of the early gothic faces is absent in the lowercase letters though the capitals retain a good many ornamental strokes. In France this style did not last long. In England, however, it was adopted and formed the basis for the development of the so-called English blackletter faces which were widely used for books in the vernacular during the sixteenth century and survived even longer for the printing of bibles. The style of the Aldebrandin typeface is thus of some importance in the history of early English printing.

\section{THE BOOK'S CONTENT}

Though the composition of the manuscripts and their derivative book is new, that is, it is not a copy or translation of any single earlier work, and the work was written in French, the content is far from original. Landouzy and Pépin give a detailed discussion of sources; in summary these are extracts from Latin translations of Arabic texts of the ninth to eleventh centuries including Avicenna, Haly Abbas and Rhazes whose content often derives, in turn, from older Greek sources."

As the author points out several times, this is not a book about the treatment of illness, rather it is concerned with healthy living and avoidance of disease; it is one of the eft plus fubtille ct plus legiere en cefte maniere pesencs ocux ozaps de couton qै foíent dun pois et baignes en oinerfes ea ues et les repofes arrierect les mectes au fouleil a feítber $z$ cel luy qui pefera moins leaue on il fera mouilie fera pius lígicze ct vaulora mienx Enco2 vous

FIGURE 2 How to tell which of two sources of water is the better. The instructions begin on the second line:'Prenes deux draps de coton....' ('Take two pieces of cotton of the same weight....') sig. biiii $v$ first column.

treatises on Regimen sanitatis which were popular at the time. Nor, despite its apparently having been composed for Béatrix de Savoie on the occasion of her visiting her royal daughters, is it particularly directed towards the health of princes or the aristocracy. A table in the section missing from our copy sets out the contents. Briefly these give advice on where to live, and on what, when and how much to eat and drink. Then the benefits and drawbacks of various particular foods are listed, there is a brief piece on conjugal relations, sections on preserving the function of various parts of the body, a chapter of advice for pregnant women and one on instruction for new mothers and nurses on care of the newborn and the infant. Finally the work ends with a chapter on physiognomy.

It is impracticable to reproduce extensive passages here but I shall give a couple of examples which indicate how different mediæval concepts were from ours. Aldebrandin discusses the importance of water to health and advises how to tell good from bad water sources. As well as clarity, a characteristic of good water is its 'subtlety and lightness'; without attempting for the moment to explain just what this quality was we may examine how Aldebrandin suggests it can be detected.

He says (Figure 2) '... to find out which of two sources is the more subtle and the lighter, proceed as follows. Take two pieces of cotton cloth of the same weight and soak them in different water [sources] then re-weigh them and put them in the sun to dry; and the water in which the one which weighs the less was soaked is the lighter and better.'

Understanding the author's reasoning presents some difficulty to the modern mind; to the contemporary reader of the book it may have been less than clear for another reason. The translation above has been corrected from the manuscript. The printed text says, in fact, that after the cloths have been soaked, we should les reposez 
arriere' - probably 'lay them aside' - before drying them in the sun. But if we examine the transcription of manuscript A we find that this is not all that we are to do. The manuscript text says, after soaking the cloths: '... et les repeses ariere; qu'il soient ouni,....' and, for 'ouni' there is a variant reading in manuscript B: 'igal l'un de l'autre' which makes the meaning even clearer.* After ('ariere') soaking we are to re-weigh ('repeses') the wet cloths to ensure that their weights are equal before we dry them. 'Ariere' refers to time not place. Someone at some time before the compositor's copy was prepared - or perhaps the compositor himself - has written 'reposez' for 'repeses', and the explanatory phrase that they are to be 'ouni' - the same, or, more clearly, 'igal l'un de l'autre' equal (in weight), has been lost. The book just tells us to 'set them aside' but the whole point is that the two cloths are to contain the same quantity (weight) of the different waters and we should check this before we dry them. Once they are dry the lighter cloth indicates that its water was more 'subtle'. This would seem to imply that the good water is able to reduce the weight of the cloth; remember we started with two pieces of cloth weighing the same, soaked them in (different) water, then checked again that they weighed the same, that is had absorbed the same quantity of water. Then when they were dry we found one cloth had lost weight - because it was soaked in the more 'subtle' water. So this 'subtlety' apparently includes a sort of negative weight or anti-gravity, an ability to make what it acts on lighter - after the water has evaporated. Thus the 'lightness' is not so much a matter of some water's density being lower than others as a positive quality of lack of weight that it can pass on to other objects - at least when it evaporates. And hence its health-giving properties. Aldebrandin took the material in this section on the quality of water from Avicenna.t

Later in the section on drinks, Aldebrandin considers wine. After various general comments on its benefits he says that drinking wine in moderation improves all the functions of the body and continues: 'And it makes a man cheerful and debonair and wise in speech as many ancient philosophers were aware, such as those in the region of Persia who ruled people and cities; they drank good wine when they wanted to take counsel or make judgments or hold people to account because they knew, and it was apparent to them, that wine made them more subtle and

\section{NOTES}

* Manuscript $A$ is held in the Bibliothèque Nationale de France, (fonds Français 2021), and was probably written in, or soon after, 1256.

tThe 'Queen of Almaigne' was Sancie wife of Richard of Cornwall who was elected Holy Roman Emperor in January I257 (N.S).

"For details see reference I. Introduction pp. Ix-Ixix.

** For this text see Landouzy and Pépin's transcription, reference I. p. 18.

tt Avicenna, Canon, Lib. I Fen II Cap. 16 where the cloth-soaking procedure is described but without the intermediate weighing while the cloths are wet. more farseeing in their affairs' Here I have translated from the text of manuscript $A .{ }^{\prime}$

The same passage in the book shows a subtle difference; since it says: '..... many philosophers of past times such as those of the religion of Persia' where the manuscript says '... of the region of Persia'. The difference is only of two letters in a single word 'religion' instead of 'region' but the difference in meaning is profound. Scribal error? Probably, but who can say. The dangers to the meanings of texts of the 'escrivains corrunpus' - careless copyists - mentioned in the prologue to manuscript A were very real.

This passage might be an attenuated survival of Herodotus's account of the government of the Persians who, he said, considered every proposition when drunk, then again when sober or, if they were sober the first time then again when drunk, and regarded the decision as reliable only if their conclusions when drunk and when sober were the same. If it is such a survival one wonders where Aldebrandin found the story; he is most unlikely to have read Greek and the first Latin translation of Herodotus was not made until the late fifteenth century.

The section on infant care includes the advice that, if a child is slow to speak he should be encouraged to imitate sounds that 'do not require too much movement of the tongue' such as mama and papa. In the printed book this seems unremarkable but it is very interesting to philologists because the finding of 'mama' and 'papa' in the manuscript of I 256 apparently represents the first written occurrence of these very common words in French - presumably after countless years of use in the oral language.

So this rare book preserves a conspectus of mediæval medical views on healthy living and shows again how the great bulk of official medical opinion on these matters was a digest of classical writings first collected by 'Arab' - who, in fact, included Christian and Jewish - scholars and practitioners then translated into Latin from which they entered western mediæval medicine. Not until the Renaissance did the Greek texts become available.

IML Donaldson, Honorary Librarian, RCPE (email: i.m.l.d@ed.ac.uk)

\section{REFERENCES}

I Landouzy L, Pépin R. Le régime du corps de maître Aldebrandin de Sienne. Paris: Honoré Champion; I9II.

2 Littré É. Alebrand de Florence, médecin. In: Didot F, Treuttel et Wurtz. Histoire littéraire de la France. Paris: I847. p. 4I5-I8.

3 Thomas A. L'identité du médecin Aldebrandin de Sienne. Romania: I906; p. 454-56.

4 Claudin A. Histoire de L'imprimerie en France au XVe et au XVle siècle. Tome troisième. Paris: Imprimerie Nationale; 1904. p. I56-92.

5 Donaldson IML. Two states of some plates in the Compendiosa of Thomas Geminus (1545). The Library 2010; I I:89-104. 